\title{
Financial Inclusion Through Insurance \& Pension Schemes
}

\author{
Miryala Shekar ${ }^{1}$, Sabada Veeramani \\ ${ }^{1}$ Department of Accounting \& Finance, College of Business Administration, University of Hail, Hail City, Kingdom of Saudi Arabia \\ ${ }^{2}$ Department of Finance \& Accounting, Aristotle PG College, Hyderabad, India
}

Email address:

mokshitfeb22@gmail.com (M. Shekar),dr.shekar@uoh.edu.sa (M. Shekar), veeramanimiryala@gmail.com (S. Veeramani)

To cite this article:

Miryala Shekar, Sabada Veeramani. Financial Inclusion Through Insurance \& Pension Schemes. European Business \& Management. Vol. 3, No. 6, 2017, pp. 105-112. doi: 10.11648/j.ebm.20170306.12

Received: September 27, 2017; Accepted: October 27, 2017; Published: November 23, 2017

\begin{abstract}
The concept of Financial Inclusion is not a new one, which has become a catchphrase now and has attracted the global attention in the recent decades. Lack of accessible, affordable and appropriate financial services has always been a global problem. In this digital era, the banking sector has grown up tremendously but even in $21^{\text {st }}$ century, less-than $2 / 3^{\text {rd }}$ of the house hold in the India has access to banking facilities. Exclusion of large no of community from any access to financial services inhibits the growth of the country and there is evidence that financial Inclusion is crucial to eradicate poverty \& financial untouchability. From the learning of past schemes, the Humble Prime Minister of India: Mr. Namenda Mode has taken a forward steps on Financial Inclusion as one of the top most priority project of the Indian government. In this regard, the following several public welfare schemes for inclusive finance through insurance \& pension schemes have been introduced since 2014 onwards. This research paper aims at briefly addressing the status of financial inclusion in India through insurance \& pension schemes (PMJDY, PMJJBY, PMSBY, PMFBY\&APY) since 2014. The data gathered from the primary \& secondary sources and descriptive $\&$ analytical methodology have been adopted for the data presentation. In order to draw the inferences, all the condensed data being presented in two-way tabular form with cross-sectional comparative analysis have been applied by using SPSS6.0.
\end{abstract}

Keywords: Financial Inclusion, PMJDY, PMJJBY, PMSBY, PMFBY \& APY

\section{Introduction}

In India the year 2011, the United Progressive Alliance (UPA)'s government focused on expanding the banking networks in rural and unbanked areas in order to achieve inclusive finance. The initiative called "Swabhimaan", with a target to ensure a bank branch in all the villages with population of 2,000 or more by March 2012. The banks in general were directed to open "no-frill" accounts. The "nofrill" accounts are the basic savings accounts with no minimum balance and fewer paperwork requirements. More than 80 per cent of accounts opened under financial inclusion program of UPA government have remained dormant. Out of the 5.92 lakh villages in the country, only 74,000 villages could be covered by this scheme. Besides, only 3.9 million account holders out of 18.2 million no-frills accounts availed overdraft facilities amounting to Rs 155 core.

The concept of Financial Inclusion is not a new one. It has become a catchphrase now and has attracted the global attention in the recent decades. Lack of accessible, affordable and appropriate financial services has always been a global problem. It is estimated that about 2.9 billion people around the world do not have access to formal sources of banking and financial services. Therefore in India, Financial inclusion is intended to connect people to banks with consequential benefits, ensuring that the financial system plays its due role in promoting inclusive growth in one of the biggest challenges facing the emerging economies. From the learning of past schemes failure-ness, honorable Prime Minister of India: Mr. Namenda Modi has taken a forward steps on Financial Inclusion, which is as one of the top most priority project of the government, in this regard, several public welfare schemes for inclusive finance through insurance \& pension schemes have been introduced since 2014 onwards such as PMJDY, PMJJBY, PMSBY, PMFBY\&APY.

In this context, Government of India (GOI) launched four 
ambitious Social Security Schemes pertaining to the Insurance and Pension Sectors on 9th May, 2015. Namely Pradhan Mantri Jeevan Jyoti Bima Yojana (PMJJBY), Pradhan Mantri Suraksha Bima Yojana (PMSBY) and an the Atal Pension Yojana (APY) and one for crop insurance, i.e., Pradhan Mantri Fasal Bema Yojana (PMFBY) to move towards creating a universal social security system, targeted especially for the poor and the under-privileged. These schemes are expected to serve the goal of financial inclusion by achieving penetration of insurance down to the weaker sections of the society, ensuring their or their family's financial security, which otherwise gets pulled to the ground in case of any unexpected and unfortunate accident.

Financial inclusion provides formal identity, access to payments system \& deposits to all the households in the country with financial services, with particular focus to empower the weaker sections of the society, including women, small and marginal farmers and laborers of both rural and urban.

\section{Review of Literature}

In order to clearly understand the gravity of the financial inclusion topic, an extensive review of various reports, working papers, dissertations and academic journals were reviewed, out of which, few of them have been listed here.

The authors [7], [9], [12], [13] tries to find out level of financial literacy in India \& explained the current scenario of the Financial Sector, providing recommendations, giving a direction and providing changes that can be implemented to modify the existing policies, propelling India to become the next super power keeping in mind the undervalued importance of financial literacy. And also addressed the influencing factors of financial literacy, Role of concerned Regulatory authorities for promoting financial literacy and authors concluded that the financial literacy status is not satisfactory, especially in rural areas and the people are not aware of financial services offered.

The scholars [11], [20], [21] presented the comprehensiveness of the new initiatives taken through PMJJBY, PMSBY \& APY for the informal workers \& under-privileged people in insurance sectors and also explained how to overcome the barriers in implementation of the schemes.

The same hypothesis has been used by [5], [17], [18] to address the impact of PMJDY on Financial inclusion in India. PMJDY is an ambitious financial inclusion program to eradicate financial untouchability by opening bank accounts for the poorer section and also sketched the recent trends in financial inclusion, highlighting its key areas and suggested strategies to ensure maximum financial inclusion for the disadvantaged and unbanked areas.

The authors [4], [10], [16] are made an attempt to highlight the recent trends in financial inclusion in India with special reference to PMJDY and measures to improve financial inclusion and also paid an attention on trends of accounts opened under PMJDY Scheme and suggested strategies to create awareness on financial literacy activities and also suggested that the success of the scheme is required constant review and monitoring.

[2],[4], [15] Discussed the overview of financial inclusion status through PMJDY scheme and analyzed the performance, benefits, issues \& challenges and future prospects of PMJDY scheme in order to achieve the results of financial inclusion.

The scholars [1], [8], [19] addressed the impact of demonetization on financial inclusion, with the aim of achieving financial inclusion along with making India as a cashless and digital economy and found that has created a tremendous impetus towards greater financial inclusion and also suggested that the continuous efforts are required to make technology to reach the bottom of the society.

[22] Published report reviews, the economic developments world over and states possible future projections with regard to the World Economy. The report reveals that global economic recovery will continue to be uncertain and global economic growth will decline further.

Authors [3], [6], [14] focused on Unique Solutions to attain the financial inclusion and presented, various measures taken by the government of India since globalization and also compared the degree of financial inclusion in India with other emerging and advanced economies with pre \& post liberalization. It is intended to connect people to financial markets \& financial institutions with consequential benefits and conducted a large scale survey to investigate the relevance of social interaction and caste affiliation on saving patterns of India. In contrast, the study found a weak empirical evidence for the effect of social interaction and caste affiliation on investment behavior of households.

\section{Need for the Study}

In the recent decades, the banking sector has grown up tremendously but usurious money lenders are continuing to exploit the poorer section of the society, economic and social inequalities have increased along with high growth rates in India, because more than $1 / 3^{\text {rd }}$ of the households are excluded from banking activities. The importance of financial inclusion arises from the problem of financial exclusion as a result. Inclusive growth is essential for sustainable development and equitable distribution of wealth and prosperity.

\section{Objectives of The Study}

1. To address the financial inclusion in India

2. To study the selected insurance and pension schemes

3. To review the features of PMSBY\& PMJJBY schemes

4. To offer suggestions for better implementation of the PMJDY, PMSBY\& PMJJBY \&APY

\section{Research Methodology}

The data has been gathered through primary \& secondary source. Primary data has been collected from the fifty five 
respondents by circulating questionnaire and Secondary data has been gathered through RBI bulletin, reports, statistical abstracts, websites of RBI, OECD, PMJDY, PMSBY, PMFBY, APY and Ministry of Finance and other useful sources, reputed journals \& newspapers. The present study is descriptive, comprehensive analytical in nature, for analysis, all the condensed data being presented in two-way tabular form with cross-sectional comparative analysis for drawing the inferences.

\section{Sample Size}

In the present study, fifty five respondents were selected randomly as sample size from the rural \& urban area of the Ranga reddy district in Telangana state, India.

\section{Scope \& Period of the Study}

The scope of the present study is confined to the inclusive finance in India through insurance \& pension schemes (PMJDY, PMJJBY, PMSBY, PMFBY\&APY) for the period of 17 years (from: 2001 to 2016).

\section{Data Analysis}

\subsection{Financial Inclusion in India}

In recent decades, economic and social inequalities have increased along with high growth rates in India. It is not possible for us to sustain our growth process if we fail to include a huge number of vulnerable groups in our mainstream society. As result, Inclusive growth has become a national policy objective of the government of India and which is possible only through Financial Inclusion. In India, the concept of financial inclusion was first incorporated in 2005, when it was introduced by K. C. Chakravarthy, the chairman of Indian Bank. Mangalam Village, turn out to be the first village in India where all households were provided banking facilities. Norms were relaxed for those people who were planning to open accounts with annual deposits of less than Rs. 50,000. General credit cards (GCCs) were issued to the poor and the underprivileged with outlook to help them access easy credit. In January 2006, the Reserve Bank allowed commercial banks to make use of the services of non-governmental organizations (NGOs/SHGs), microfinance institutions, and other civil society organizations as intermediaries for providing financial and banking services. These intermediaries could be used as business facilitators or business correspondents by commercial banks. The bank asked the commercial banks in different regions to start a $100 \%$ financial inclusion campaign on a pilot basis. As an outcome of the campaign states or U. T. s like Pondicherry, Himachal Pradesh and Kerela declared $100 \%$ financial inclusion in all their districts. Reserve Bank of Indiaes visualization for 2020 is to open nearly 600 million new customers $^{\text {ee }}$ accounts and service them through a diversity of channels by leveraging on IT. However, illiteracy and the low income savings and lack of bank branches in rural areas remain to be an obstruction to financial inclusion in many states and there is inadequate legal and financial infrastructure.

Swabhiman scheme: The financial inclusion program of the UPA government was focused on expanding the banking networks in rural and unbanked areas. The initiative called "Swabhimaan" that started in 2011 set a target to ensure a bank branch in all the villages with population of 2,000 or more by March 2012.

\subsection{Present Status of Financial Inclusion in India}

In India, various initiatives were taken up by RBI / GOI in order to ensure financial inclusion. These include like Nationalization of Banks, Expansion of Banks branch network, Establishment \& expansion of Cooperative and RRBs, Introduction of PS lending, Lead Bank Scheme, Formation of SHGs and State specific approach for Govt sponsored schemes to be evolved by SLBC, PMJDY (2014), PMSBY (2015), PMJJBY(2015), APY (2015) \& Demonetization (2016). During 2005-2006, RBI advised Banks to align polices with the objective of financial Inclusion. Further, in order to ensure greater financial inclusion and increasing the outreach of the banking sector, it was decided to use the services of NGOs/SHGs, MFIs and other Civil Society Organizations as intermediaries in providing financial and banking services through use of Business Facilitator and Business Correspondent Model. In India, after imposition of demonetization, digital banking has been increased tremendously.

Table 1. Households Penetration of availing banking Services as per 2001 and 2011 Census.

\begin{tabular}{|c|c|c|c|c|c|c|}
\hline & As per Census 2001 & & & As per Census 2011 & & \\
\hline Households & $\begin{array}{l}\text { Total no of } \\
\text { Households }\end{array}$ & $\begin{array}{l}\text { No of Households availing } \\
\text { banking services }\end{array}$ & $\%$ & $\begin{array}{l}\text { Total no of } \\
\text { Households }\end{array}$ & $\begin{array}{l}\text { No of Households availing } \\
\text { banking services }\end{array}$ & $\%$ \\
\hline Rural & $138,271,559$ & $41,639,949$ & 30.1 & $167,826,730$ & $91,369,805$ & 54.4 \\
\hline Urban & $53,692,376$ & $26,590,693$ & 49.5 & $78,865,937$ & $53,444,983$ & 67.8 \\
\hline Total & $191,963,935$ & $68,230,642$ & 35.5 & $246,692,667$ & $144,814,788$ & 58.7 \\
\hline
\end{tabular}

Source: http://financialservices.gov.in/banking/Overviewofefforts.pdf

Interpretation: On the basis of the above tabular data, it is noticed that the accessing banking services in rural and urban has been increased from 30.1 percent, to 54.4 percent and 49.5 percent to 67.8 percent respectively in the years 2001 and 2011. As per the table 1, rural and urban people are participating in the financial services with the banking sector has grown up rapidly. 


\subsection{Selected Insurance \&Pension Schemes}

Government of India, launched five ambitious Social Security Schemes pertaining to the Insurance and Pension Schemes, such as PMJDY, PMSBY, PMJJBY, APY \& PMFBY to move towards creating a universal social security system, targeted especially for the poor and the underprivileged sections of the rural as well as urban areas since 2014on wards for the have not's.

\subsubsection{Pradhan Mantri Jan Dhan Yojana (PMJDY)}

Prime minster of India, has announced PMJDY in his $1^{\text {st }}$ Independence Day speech $15^{\text {th }}$ August 2014, this new scheme "PMJDY (Prime Minister People money scheme)" as a National Mission for comprehensive financial inclusion. And launched on $28^{\text {th }}$ August 2014, for weaker section of the community as an integrated approach for the financial freedom \& financial literacy [23], [24], [25], [34], [35] PMJDY works on the principles of "SAB KA SATH SAB KA VIKAS" \& "Mera Khata Bhagyavidhata", which means "my account is divine'. The Main Objective of the PMJDY is financial inclusion and access to financial services for all the households above the age of 10 years in the country. Under this scheme every account holders to be provided zero balance bank account with over draft of Rs 5000 after 6 months and a RuPay Debit Card with an accidental insurance cover of Rs 1 lakh and the scheme got a certificate from the 'Guinness Book of World Records' for 1.5 core bank accounts were opened on the inaugural day across the country.

Table 2. Progress of PMJDY as on 13.09.2017 (All Figures in Crores).

\begin{tabular}{|c|c|c|c|c|c|c|c|}
\hline \multirow[b]{2}{*}{ Category } & \multicolumn{6}{|c|}{ No of accounts opened under PMJDY } & \multirow{2}{*}{ No of RuPay Cards } \\
\hline & Rural & $\%$ & Urban & $\%$ & Total & $\%$ & \\
\hline 1. PSBs & 13.31 & 44 & 11.07 & 36 & 24.38 & 80 & 18.30 \\
\hline 2. RRBs & 4.12 & 14 & 0.77 & 3 & 4.89 & 17 & 3.60 \\
\hline 3. $\mathrm{PBs}$ & 0.59 & 2 & 0.38 & 1 & 0.97 & 3 & 0.90 \\
\hline Total & 18.02 & 60 & 12.22 & 40 & 30.24 & 100 & 22.80 \\
\hline
\end{tabular}

Secondary Source: PMJDY Progress Report -2017 [25]

Interpretation: As per the above table no 2, The performance of the financial institutions in terms of opening bank accounts \& issuing RuPay debit cards in the past three year period is noticed that the 30.24 cores accounts have been opened out of which $60 \%$ in rural $\& 40 \%$ in urban and $75 \%$ RuPay Cards have been issued as on $13^{\text {th }}$ September 2017. Public Sector Banks (PSBs) is stood at the top with $80 \%$ followed by Regional Rural Banks (RRBs) and Private Banks (PBs) with 17\% and 3\% respectively.

\subsubsection{Pradhan Mantri Suraksha Bima Yojana (PMSBY)}

In light of the fact that a large proportion of the population have no accidental insurance cover, the Pradhan Mantri Suraksha Bima Yojana (PMSBY) is aimed at covering the uncovered population at an highly affordable premium of just Rs.12 per year [26], [30], [34], [36], [37], [38]. The Scheme will be available to people in the age group 18 to 70 years with a savings bank account who give their consent to join and enable auto-debit on or before 31st May for the coverage period 1st June to 31 st May on an annual renewal basis. Under the said scheme, risk coverage available will be Rs. 2 lakh for accidental death \& permanent total disability and Rs. 1 lakh for permanent partial disability, for a one year period stretching from 1st June to 31 st May. It is offered by Public Sector General Insurance Companies or any other General Insurance Companies. Further, in order to assure a hassle free claim settlement experience for the claimants a simple and subscriber friendly administration \& claim settlement process has been put in place. To ensure that the benefits of this scheme are brought to every uninsured individual, who hold the bank account?

Claim Process: Claim settlement will be made to the bank account of the insured or his nominee in case of death of the account holder by submitting death certificate and simple claim form.

\subsubsection{The Pradhan Mantri Jeevan Jyoti Bima Yojana (PMJJBY)}

This scheme is a one year life insurance scheme, renewable from year to year, offering coverage for death due to any reason and is available to people in the age group of 18 to 50 years (life cover up to age 55) having a savings bank account who give their consent to join and enable auto-debit. The risk cover on the lives of the enrolled persons has commenced from 1st June 2015. Life cover of Rs. 2 lakhs is available for a one year period stretching from 1st June to 31st May at a premium of Rs.330/- per annum per member and is renewable every year. It is offered / administered through LIC and other Indian private Life Insurance companies, for enrolment banks have tied up with insurance companies \& participating Bank is the Master policy holder and Individuals who exit the scheme at any point may re-join the scheme in future years by paying the annual premium and submitting a self-declaration of good health. The assurance on the life of the member shall terminate on any of the following events and no benefit will become payable there under [26], [31].

a) On attaining age 55 years (age near birth day) subject to annual renewal up to that date (entry, however, will not be possible beyond the age of 50 years).

b) Closure of account with the Bank or insufficiency of balance to keep the insurance in force.

c) A person can join PMJJBY with one Insurance company with one bank account only. 
Claim Process: In case of claim the nominees/heirs of the insured person have to contact respective bank branch where the insured person was having bank account. A death certificate and simple claim form is enquired to submit and the claim amount will be transferred to nominees account.

\subsubsection{Atal Pension Yojana (APY)}

APY is open to all bank account holders, the Central Government would also co-contribute $50 \%$ of the total contribution or Rs. 1000 per annum, whichever is lower, to each eligible subscriber, for a period of 5 years, i.e., from Financial Year 2015-16 to 2019-20, who join the APY before 31st December, 2015, and who are not members of any statutory social security scheme and who are not income tax payers. That's why, APY focused on all citizens in the unorganized sector. Under APY, the monthly pension would be available to the subscriber, and after him /her to his spouse and after their death, the pension corpus, as accumulated at age 60 of the subscriber, would be returned to the nominee of the subscriber and the subscribers would receive the fixed minimum pension of Rs.1000, Rs. 2000, Rs. 3000, Rs. 4000, Rs. 5000 per month respectively at the age of 60 years, depending on their contributions, which itself would be based on the age of joining the APY. Therefore, the benefit of minimum pension would be guaranteed by the Government. However, if higher investment returns are received on the contributions of subscribers of APY, higher pension would be paid to the subscribers [32], [36], [37], [38].

Interpretation: In table 3, it's noticed that the different slabs for the monthly, quarterly \& half-yearly contributions under APY@ different minimum guaranteed amount of pension for different age entry $\&$ return of the corpus amount to the nominees. A subscriber joining the scheme of Rs. 1,000 monthly pension at the age of 18 years would be required to contribute Rs. 42 per month. However, if he / she joins at age 40, he has to contribute Rs. 291 per month. Similarly, a subscriber joining the scheme of Rs.5,000 monthly pension at the age of 18 years would be required to contribute Rs. 210 per month. However, if he joins at age 40, he has to contribute Rs. 1,454 per month to receive the same pension amount. Therefore, it is better to join early in the Scheme. The minimum age of joining APY is 18 years and maximum age is 40 years. Therefore, minimum period of contribution by any subscriber under APY would be 20 years or more. So early you avail less you contribute. Moreover $50 \%$ of this contribution will be paid by GOI if subscriber is not covered from any other social security scheme and he/ she is not a tax payer.

Table 3. Statement showing monthly, quarterly \& half-yearly contributions under APY@ different minimum guaranteed amount of pension for different age entry \& return of the corpus amount to the nominee.

\begin{tabular}{|c|c|c|c|c|c|c|c|c|c|c|c|c|c|c|c|c|}
\hline \multirow{2}{*}{\multicolumn{2}{|c|}{$\begin{array}{l}\text { Return of corpus } \\
\text { to the nominee }\end{array}$}} & \multirow{2}{*}{\multicolumn{3}{|c|}{$\begin{array}{l}\text { Minimum } \\
\text { guaranteed pension } \\
\text { of rs1000 PM } \\
\text { Rs } 1.70 \text { Lakh } \\
\end{array}$}} & \multirow{2}{*}{\multicolumn{3}{|c|}{$\begin{array}{l}\text { Minimum guaranteed } \\
\text { pension of rs2000 PM }\end{array}$}} & \multicolumn{3}{|c|}{$\begin{array}{l}\text { Minimum guaranteed } \\
\text { pension of rs3000 PM }\end{array}$} & \multirow{2}{*}{\multicolumn{3}{|c|}{$\begin{array}{l}\text { Minimum guaranteed } \\
\text { pension of rs4000 PM }\end{array}$}} & \multicolumn{3}{|c|}{$\begin{array}{l}\text { Minimum guaranteed } \\
\text { pension of rs5000 PM }\end{array}$} \\
\hline & & & & & & & & Rs 5. & Lakh & & & & & Rs 8. & Lakh & \\
\hline \multirow{2}{*}{$\begin{array}{l}\text { Age at } \\
\text { entry }\end{array}$} & \multirow{2}{*}{$\begin{array}{l}\text { Vesting } \\
\text { period }\end{array}$} & \multicolumn{3}{|c|}{ Installment } & \multicolumn{3}{|c|}{ Installment } & \multicolumn{3}{|c|}{ Installment } & \multicolumn{3}{|c|}{ Installment } & \multicolumn{3}{|c|}{ Installment } \\
\hline & & PM & QLY & HLY & PM & QLY & HLY & PM & QLY & HLY & $\mathbf{P M}$ & QLY & HLY & PM & QLY & HLY \\
\hline 18 & 42 & 42 & 125 & 248 & 84 & 250 & 496 & 126 & 376 & 744 & 168 & 501 & 991 & 210 & 626 & 1239 \\
\hline 19 & 41 & 46 & 137 & 271 & 92 & 274 & 543 & 138 & 411 & 814 & 183 & 545 & 1080 & 228 & 679 & 1346 \\
\hline 21 & 39 & 54 & 161 & 319 & 108 & 322 & 637 & 162 & 483 & 956 & 215 & 641 & 1269 & 269 & 802 & 1588 \\
\hline 22 & 38 & 59 & 176 & 348 & 117 & 349 & 690 & 177 & 527 & 1045 & 234 & 697 & 1381 & 292 & 870 & 1723 \\
\hline 23 & 37 & 64 & 191 & 378 & 127 & 378 & 749 & 192 & 572 & 1133 & 254 & 757 & 1499 & 318 & 948 & 1877 \\
\hline 24 & 36 & 70 & 209 & 413 & 139 & 414 & 820 & 208 & 620 & 1228 & 277 & 826 & 1635 & 346 & 1031 & 2042 \\
\hline 25 & 35 & 76 & 226 & 449 & 151 & 450 & 891 & 226 & 674 & 1334 & 301 & 897 & 1776 & 376 & 1121 & 2219 \\
\hline 26 & 34 & 82 & 244 & 484 & 164 & 489 & 968 & 246 & 733 & 1452 & 327 & 875 & 1930 & 409 & 1219 & 2414 \\
\hline 27 & 33 & 90 & 268 & 531 & 178 & 530 & 1050 & 268 & 799 & 1582 & 356 & 1061 & 2101 & 446 & 1329 & 2632 \\
\hline 29 & 31 & 106 & 316 & 626 & 212 & 632 & 1251 & 318 & 948 & 1877 & 423 & 1261 & 2496 & 529 & 1577 & 3122 \\
\hline 30 & 30 & 116 & 346 & 685 & 231 & 688 & 1363 & 347 & 1034 & 2048 & 462 & 1377 & 2727 & 577 & 1720 & 3405 \\
\hline 31 & 29 & 126 & 376 & 744 & 252 & 751 & 1487 & 379 & 1129 & 2237 & 504 & 1502 & 2974 & 630 & 1878 & 3718 \\
\hline 32 & 28 & 138 & 411 & 814 & 276 & 823 & 1629 & 414 & 1234 & 2443 & 551 & 1642 & 3252 & 689 & 2053 & 4066 \\
\hline 33 & 27 & 151 & 450 & 891 & 302 & 900 & 1782 & 453 & 1350 & 2673 & 602 & 1794 & 3553 & 752 & 2241 & 4438 \\
\hline 34 & 26 & 165 & 492 & 974 & 330 & 983 & 1948 & 495 & 1475 & 2921 & 659 & 1964 & 3889 & 824 & 2456 & 4863 \\
\hline 35 & 25 & 181 & 539 & 1068 & 362 & 1079 & 2136 & 543 & 1618 & 3205 & 722 & 2152 & 4261 & 902 & 2688 & 5323 \\
\hline 36 & 24 & 198 & 590 & 1169 & 396 & 1180 & 2337 & 594 & 1770 & 3506 & 792 & 2360 & 4674 & 990 & 2950 & 5843 \\
\hline 37 & 23 & 218 & 650 & 1287 & 436 & 1299 & 2573 & 654 & 1949 & 3860 & 870 & 2593 & 5134 & 1087 & 3239 & 6415 \\
\hline 38 & 22 & 240 & 715 & 1416 & 480 & 1430 & 2833 & 720 & 2146 & 4249 & 957 & 2852 & 5648 & 1196 & 3564 & 7058 \\
\hline 39 & 21 & 264 & 787 & 1558 & 528 & 1574 & 3116 & 792 & 2360 & 4674 & 1054 & 3141 & 6220 & 1318 & 3928 & 7778 \\
\hline 40 & 20 & 291 & 867 & 1717 & 582 & 1734 & 3435 & 873 & 2602 & 5152 & 1164 & 3469 & 6869 & 1454 & 4333 & 8581 \\
\hline
\end{tabular}

Source: Secondary data [32]

\subsubsection{Pradhan Mantri Fasal Bima Yojana (PMFBY)}

In order to make crop insurance simpler and cheaper for the farmers [27], [28], [35], [36], [39] and to provide them with better insurance services, the GOI launched the Pradhan
Mantri Fasal Bima Yojana on $11^{\text {th }}$ October2014 by replacing NAIS and MNAIS \& which has been implemented from the kharif season of the year 2016 onwards. The main Objective of PMFBY is to provide insurance cover for the rabi and 
kharif crops and financial support to farmers in case of damage of crops. Under this scheme, farmers will have to pay a uniform premium of two per cent for all kharif crops and 1.5 per cent for all rabi crops [33].

Interpretation: The table 4 and figure 1 shows that the awareness level of the 55 respondents on PMJDY, APY,
PMJJBY \&PMSBY schemes in rural \& urban areas, Respondents of the urban areas are more aware about the social security schemes \& PMSBY stood with $82 \%$ as compare to PMJDY, APY\&PMJJBY and APY occupied last position with $55 \%$.

Table 4. Awareness about insurance \& pension schemes in rural \& urban areas.

\begin{tabular}{lllll}
\hline \multirow{2}{*}{ Schemes } & \multicolumn{3}{c}{ Schemes * Areas Cross tabulation } \\
\cline { 3 - 4 } & & Ureas & Rural & Total \\
\hline \multirow{2}{*}{ PMJDY } & Count & 40 & 15 & 55 \\
& $\%$ within Schemes & $72.7 \%$ & $27.3 \%$ & $100.0 \%$ \\
\multirow{2}{*}{ APY } & Count & 30 & 25 & 55 \\
& \% within Schemes & $54.5 \%$ & $45.5 \%$ & $100.0 \%$ \\
\multirow{2}{*}{ PMJJBY } & Count & 35 & 20 & 55 \\
& \% within Schemes & $63.6 \%$ & $36.4 \%$ & $100.0 \%$ \\
\multirow{2}{*}{ PMSBY } & Count & 45 & 10 & 55 \\
& \% within Schemes & $81.8 \%$ & $18.2 \%$ & $100.0 \%$ \\
\multirow{2}{*}{ Total } & Count & 150 & 70 & 220 \\
\hline
\end{tabular}

Source: Primary data

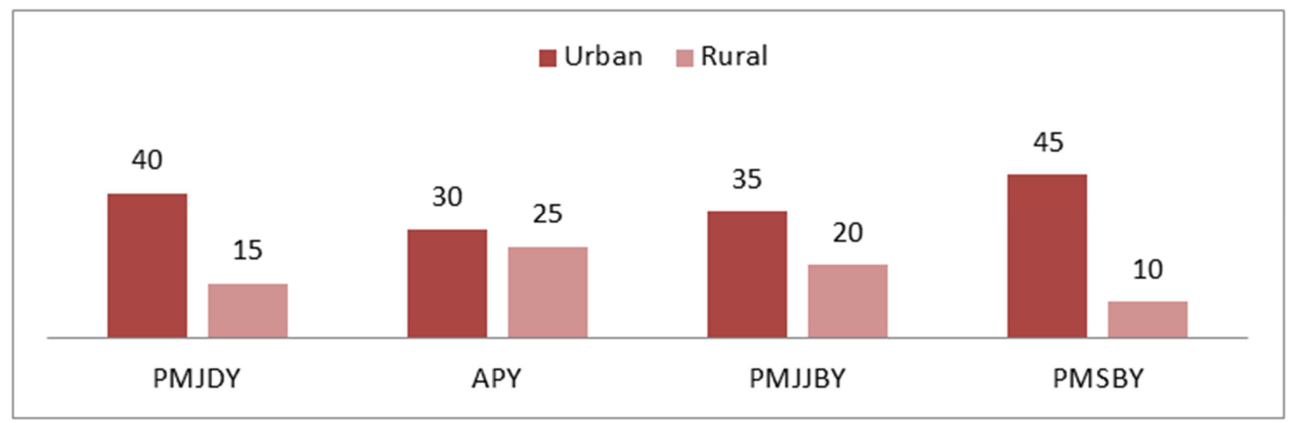

Figure 1. Awareness about insurance \& pension schemes in rural \& urban areas.

Interpretation: As per table $5 \&$ figure 2 (pie diagram), wide publicity was given on the above said social security schemes through posters, brochures, pamphlets, banners, print \& electronic media \& e-channels including social media and 7.29 Crores number enrolled under PMSBY as on $31^{\text {st }}$ may 2015. The sources of TV \& newspapers are placed $1^{\text {st }} \&$ $2^{\text {nd }}$ ranks in creating awareness among the underprivileged sections of the society. Further, an expenditure of Rs. 2,000 crore for promotional and developmental activities for enrolment and contribution collection under APY and Rs. 250 crore for publicity, awareness building for PMJJBY and PMSBY is envisaged by the Government, over a period of five years.

Table 5. Sources for getting the awareness on PMJDY, APY, PMJJBY \&PMSBY schemes.

\begin{tabular}{llll}
\hline Sources & No. of Respondents & \% & Rank \\
\hline Television & 25 & 45 & 1 \\
Newspaper & 15 & 27 & 2 \\
E-channels (Social Media) & 10 & 18 & 3 \\
Others & 5 & 9 & 4 \\
\hline
\end{tabular}

Source: Primary data

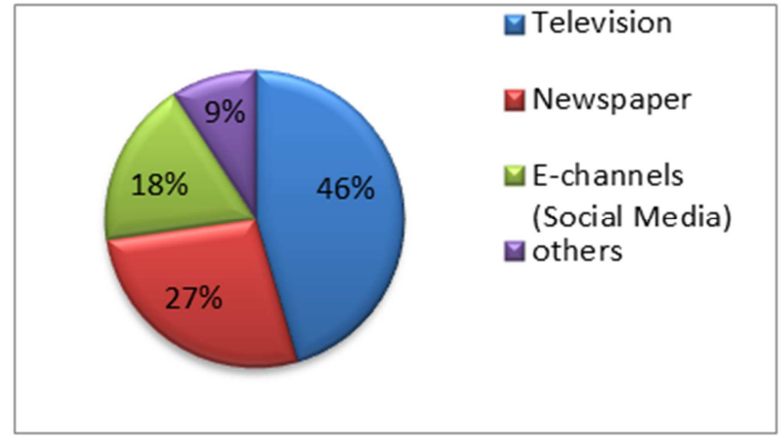

Figure 2. Sources for getting the awareness on PMJDY, APY, PMJJBY $\& P M S B Y$ schemes.

\section{Conclusion \& Suggestions}

This study clearly addressed the financial inclusion through insurance \& pension schemes, which began to provide social security benefit to large number of people of the unorganized sectors. The subscribers for these schemes are at increasing pace, however if implemented still more properly and the benefit is passed on to the real subscriber it will go a long way in establishing a social security system to 
the large section of society which has remained uncovered. The both urban and rural people are almost equally obtaining these schemes, the Government expenditure is expected to spend the range between Rs. 2,520 crore and Rs. 10,000 crore on account of the government co-contribution to subscribers of the APY over a period of five years. Finally, suggested that the continuous efforts are required from the financial institutions to achieve the inclusive financial growth at the ground level of the society through insurance and pension schemes with special reference to PMJDY, PMSBY, PMJJBY, APY \& PMFBY.

\section{References}

[1] Banik. N and Padalkar. M. (2016), India's Demonetization: Time for a Digital Economy, The Diplomat, 01 December 2016. Retrieved from http://thediplomat.com/2016/12/indiasdemonetization-time-for-a-digital-economy/

[2] Brij Mohan. (2014), "Pradhan Manti Jan Dhan Yojana (PMJDY): Features, Needs And Challenges", International Journal Of Marketing, Financial Services \& Management Research, ISSN 2277-3622, Vol.3 (12), pp. 111-117. 6

[3] Bonte, W. a. (2012). Financial literacy, information flows, and caste affiliation: Empirical evidence from India. Journal of Banking \& Finance, 36, 3399-3414

[4] Divyesh Kumar. (2014),"Financial Inclusion Using Pradhan Mantri Jan-Dhan Yojana -A Conceptual Study", Asia Pacific Journal of Research ISSN: 2320-5504, E-ISSN-2347-4793, Vol.1 (20), pp.37-42

[5] Harpreet Kaur \& Kawal Nain Singh. (2015), "Pradhan Mantri Jan Dhan Yojana (PMJDY): A Leap towards Financial Inclusion in India", International Journal of Emerging Research in Management \&Technology, Vol. 4 (1), pp. 25-29

[6] Kumar, V. (2014), Financial Inclusion in India: Unique Solutions, Indian Streams Research Journal, Vol. 4, No. 8, pp. $1-3$

[7] Lavanya Rekha Bahadur (2016), Financial Literacy: The Indian Story, World Journal of Social Sciences Vol. 5. No. 3. September 2015 Issue. Pp.45-57

[8] Partap Singh \& virender singh. (2016), Impact of demonetization on Indian economy, ICRISTME-16, ISBN: 978-93-86171-13-9, pp.290-299

[9] Pratima Trevedi \& Saumya Trevedi. (2016), Financial Literacy an Essential Prerequisite for Financial Inclusion, Global Journal for Research Analysis, ISSN:2277-8160, Issue.3, pp.28-30

[10] Rajanikanta Khuntia. (2014), "Pradhan Mantri Jan Dhan Yojana (PMJDY): A New Drive towards Financial Inclusion in India", ZENITH International Journal of Business Economics \& Management Research, Vol. 4 (11), pp.10-20

[11] Rajesh K. Yadav \& Sarvesh Mohania (2016), Pradhan Mantri Jeevan Jyoti Bima Yojana- A Case Study of Pradhan Mantri Jan Dhan Yojana, World Scientific News WSN31(2016) 3546, EISSN 2392-2192

[12] Ramaswamy D., e. a. (2013). A Study of the Level of Awareness of Financial Literacy among Management undergraduates, Proceedings of 3rd Asia-Pacific Business Research Conference. Kuala Lumpur

[13] Shanker Kumar. SJ, Aftab Ahmad. S \& Shekar, M.(2017), Financial Literacy as a Tool of Financial Inclusion, Airo International Research Journal, ISSN:23203714, Voll. IX

[14] Sharma. M (2016), what does India'a demonetization Experiment Mean for Financial Inclusion?, Centre for Financial Inclusion Blog, 16 November 2016. Retrieved from https://cfi-blog.org/2016/11/16/what-does-indiasdemonetization-experiment-mean-for-financial-inclusion

[15] Shekar, M.(2017), Financial Inclusion through PMJDY: Pre \& Post Demonetization, Airo International Research Journal, ISSN:23203714, Voll. IX

[16] Sonam Kumari Gupta. (2015), "Performance Appraisal of the Pradhan Mantri Jan Dhan Yojana", IOSR Journal of Business and Management (IOSR-JBM), vol.17, (9), Ver. I, pp.35-39

[17] Suresh. A, Srinivasa Narayana \&Vijay Kumar. (2016), A Study on Financial Inclusion Initiatives and Challenges in India With Reference to PMJDY, IRA-International Journal of Management \& Social Sciences, ISSN 2455-2267; Vol.03, Issue 03

[18] Veeramani. S (2015), Pradhan Mantri Jan Dhan Yojana ( PMJDY) As A National Mission For Financial Inclusion, ELK Asia Pacific journal, special issue No: 978-81-930411-30

[19] Veeramani. S. (2017), Impact of Demonetization on Indian Economy, Airo International Research Journal, ISSN:23203714, Voll. IX

[20] Vibha Johia (2017), Roadmap to Social Inclusion through Financial Inclusion: Pradhan Mantri Jeevan Jyothi Bima Yojana, Pradhan Mantri Suraksha Bima Yojana \&Atal Pension Yojana, International Journal of Scientific \& Engineering Research (IJSER@2017), vol.8, Issue2, pp.12491263

[21] Vidyashree DV, Pralhad Rathod (2015), Financial InclusionA study on Modi's PMJJBY, PMSBY \& APY, International Journal of Applied Research, vol.1(17):632-635

[22] World Economic Outlook. (2013), International Monetary Fund (2013), viewed29thDecember2013, http://www.imf.org/external/pubs/ft/weo/2011/02/pdf/text.pd

[23] Department of Financial Services, Ministry of Finance, GoI, PMJDY Mission document https://financialservices.gov.in/Banking/PMJDY\%20brochure $\%$ pdf.

[24] Pradhan Mantri Jan Dhan Yojana (2016) Retrieved from http://www/en.wikipedia.org/wiki Pradhan_Mantri_Jan_Dhan_Yojana.

[25] Pradhan_Mantri_Jan_Dhan_Yojana (2016) / http://www.pmjdy.gov.in

[26] https://www.irdai.gov.in

[27] www.finmin.nic.in/

[28] https:// www.financialservices.gov.in

[29] https://www.oecd.org

[30] http://financialservices.gov.in/PMSBY.asp 
[31] http://financialservices.gov.in/PMJJBY.asp

[32] http://financialservices.gov.in/APY.asp

[33] http://agricoop.nic.in

[34] RBI annual report on financial inclusion - 2013-17
[35] RBI annual report on PMJDY- 2014-15 \& 16-17

[36] OECD Annual report 2016

[37] IRDA Annual report-2015-2016

[38] III Annual report-2015-2016 